\title{
Photocopying and the Copyright Law in the United States
}

The International Journal of Law Libraries recently approached Professor Julius J. Marke, Law Librarian at New York University and one of the foremost authorities on copyright law of the United States, for a review of "The Williams \& Wilkins Case". The Williams \& Wilkins Company v. The United States. Vol. 1. Marilyn G. McCormick, Compiler. New York: Science Associates/International Inc. - London: Mansell Information/ Publishing Limited, 1974. Pp. XI, 275. £ 9.75.

Professor Marke declined to review the publication for reasons stated below, but he wrote the Journal an exeptionally informative letter about the present state of copyright law in the United States with a permission that the letter be published in the Journal.

The Williams \& Wilkins Case aroused a considerable amount of attention among librarians in the United States and in the rest of the world a few years ago. The case arose from an action by a leading United States publisher of scholarly periodicals against the National Library of Medicine and The National Institute of Health for alleged unauthorized photocopying of copyrighted materials in the ordinary course of the library's reference work. The U.S. Court of Claims, on appeal, held that no breach of copyright occured within the factual circumstances of this case. The publisher appealed the decision of the Court of Claims to the Supreme Court of the United States. The appeal was heard by eight judges of the Supreme Court. Four judges decided in favour of the appeal whilest the other four judges upheld the decision of the Court of Claims. Accordingly, pursuant to the rules of appellate procedure, the dicision of the Court of Claims was affirmed by a technicality of appellate procedure and without reaching a clear ruling of law on the vexed subject of photocopying of copyright works in libraries.

Further comments about the Williams \& Wilkins Case as well as recent developments of the United States copyright law appear in Professor Marke's letter:

"Dear Editor of the International Journal of Law Libraries,

I have reservations about a review of the Williams \& Wilkins Case as published by Mansell Information. For one thing, it is incomplete in that it only contains Amicus Curiae briefs for those supporting the William \& Wilkins Company but none for those supporting the defendant, such as the briefs of the American Library Association and Special Library Association. Furthermore, Volume 2 which was announced as part of the set has never been published. Volume 2 was to be based on the decision of the U.S. Supreme Court. As you know, there was no opinion in the Supreme Court but merely 4 to 4 affirmance of the Court of Claims decision. 
It also appears to me that there is not that much interest in the Williams $\&$ Wilkins Case in the library community any more because now we are all concentrating on the revision of copyright laws in the Congress. Of course, Williams \& Wilkins Case is still important in that, in a limited way, it establishes some indicia of what the courts should consider in arriving at whether a certain type of library photocopying is "fair use". The Court of Claims limited the effect of its holding to the three or four publications which the plaintiff claimed the National Library of Medicine had photographed without permission. As I recall, the court specifically stated that it was not considering the other aspects of the case which could amount to "systematic" copying. True, the librarians claim that the effect of the case is applicable to "systematic" photocopying. Publishers, of course, argue to the contrary. This is the present status of the whole case. In the meantime, the real fight is in Congress. I was in Washington on May 14th and testified before the House Subcommittee of the Committee on the Judiciary with reference to library photocopying sections of the bill, i. e., sections 107 and 108.

It might be worthwhile for you to obtain copies of the statements submitted to the Committee by both sides. If you wish, I can send you a copy of the statement I prepared for the American Association of Law Libraries.

Julius J. Marke

Professor of Law and Law Librarian.”

The Editor of the Journal thanks Professor Marke for the information. He will also endevour to obtain the relevant statements on this subject of great importance to libraries for publication in the next issue of the Journal. K. M. 